(c) Elsevier/INRA

Note

\title{
The $R N$ locus for meat quality maps to pig chromosome 15
}

\author{
D Milan ${ }^{1}$, P Le Roy ${ }^{2}$, N Woloszyn ${ }^{1}$, JC Caritez ${ }^{3}$, \\ JM Elsen ${ }^{4}, \mathrm{P}_{\text {Sellier }}{ }^{2}, \mathrm{~J}$ Gellin ${ }^{1}$
}

${ }^{1}$ INRA, laboratoire de génétique cellulaire, BP 27, 31326 Castanet-Tolosan cedex;

${ }^{2}$ INRA, station de génétique quantitative et appliquée, 78352 Jouy-en-Josas cedex;

3 INRA, domaine expérimental du Magneraud, 17700 Surgères;

4 INRA, station d'amélioration génétique des animaux, BP 27, 31326 Castanet-Tolosan cedex, France

(Received 16 December 1994; accepted 16 February 1995)

Summary - An experiment was initiated in 1990 to study the $R N$ locus, which has been shown to exert a major effect on a measurement of meat quality in pigs, the Napole technological yield (RTN). The animals used originated from a composite line (Laconie). Thirteen reference families of double backcross type $\left(R N^{-} / r n^{+} \times r n^{+} / r n^{+}\right)$were selected to search for a marker of the $R N$ locus. The present study gives the results obtained on a sample of 220 offspring for which the $R N$ allele coming from the heterozygous parent was considered as known after a segregation analysis of RTN data. A systematic approach was applied to identify markers linked to $R N$, using a panel of 63 microsatellite markers, which are informative in those families for $1700 \mathrm{cM}$ of the pig genome. The analysis of allelic segregations allowed the mapping of the $R N$ locus to chromosome 15 at a distance of $18 \mathrm{cM}$ from the marker S0088.

pig / meat quality / major gene / molecular marker / linkage

Résumé - Le locus $R N$ de qualité de la viande est situé sur le chromosome 15 du porc. Un protocole expérimental a débuté en 1990 pour étudier le locus $\mathrm{RN}$, mis en évidence par son effet majeur sur une mesure de la qualité de la viande de porc, le rendement technologique Napole (RTN). Les animaux utilisés proviennent d'une lignée synthétique (Laconie). Treize familles de référence de type double backcross $\left(\mathrm{RN}^{-} / \mathrm{rn}^{+} \times \mathrm{rn}^{+} / \mathrm{rn}^{+}\right)$ ont été choisies pour rechercher un marqueur du gène RN. La présente étude rapporte les résultats obtenus sur un échantillon de 220 descendants pour lesquels l'allèle RN reçu du parent hétérozygote est considéré comme connu, suite à une analyse de ségrégation des données de RTN. Une démarche systématique de recherche de marqueurs liés à RN a été appliquée, en utilisant un jeu de 63 marqueurs microsatellites informatifs dans ces familles pour $1700 \mathrm{cM}$ du génome porcin. L'analyse des ségrégations alléliques a permis de localiser RN sur le chromosome 15, à 18 cM du marqueur S0088.

porc / qualité de la viande / gène majeur / marqueur moléculaire / liaison génétique 


\section{INTRODUCTION}

Evidence for a major locus affecting meat quality in pigs was first suggested by Naveau (1986) and further confirmed by segregation analysis on field data in 2 commercial lines (Le Roy et al, 1990). The meat quality measurement studied was the so-called 'Napole' technological yield (RTN) (Naveau et al, 1985). The effect of the putative $R N$ locus on RTN was estimated to be about 3 phenotypic standard deviations between the means of the homozygotes, the unfavourable allele $R N^{-}$, responsible for low RTN, being fully dominant over the normal allele $r n^{+}$. An experiment was initiated in 1990 at INRA in order to confirm the existence of this major gene (Le Roy et al, 1994), to estimate its effects on production traits (Le Roy et al, 1995), and to search for marker genes of the $R N$ locus. At the same time, the development of more than 500 microsatellite markers has led to the establishment of genetic maps of the porcine genome (Rohrer et al, 1994; Archibald et al, 1995). A systematic approach was then made possible to identify the position of known genes on the chromosomes (Gellin and Chevalet, 1994). This note presents the first results obtained, with the use of an automatic sequencer, in the localization of the $R N$ locus on the porcine genome.

\section{ANIMALS}

\section{Source population}

The animals originated from the composite Laconie line, created in 1973 by the Pen ar Lan breeding company (Maxent, France) with Hampshire, Piétrain and Large White breeds in equal proportions. It is one of the lines in which the $R N$ locus was discovered (Naveau, 1986; Le Roy et al, 1990).

Using the simplified segregation analysis of Elsen and Le Roy (1989), the animals of the Pen ar Lan selection farm were identified as probably homozygous, $R N^{-} / R N^{-}$or $r n^{+} / r n^{+}$, on the basis of the RTN values of their progeny. Animals with an estimated probability of being homozygous $\left(R N^{-} / R N^{-}\right.$or $\left.r n^{+} / r n^{+}\right)$ greater than 0.99 were retained. The consistency of predicted genotypes of parents, mates and grand-parents was checked before the final choice. From $R N^{-} / R N^{-}$and $r n^{+} / r n^{+}$sows mated to $r n^{+} / r n^{+}$boars, 2 lines were established at Le Magneraud experimental farm: an experimental line from $R N^{-} / R N^{-}$dams was expected to be heterozygous $R N^{-} / r n^{+}$; and a tester line from $r n^{+} / r n^{+}$dams was expected to be homozygous $r n^{+} / r n^{+}$.

In 1990-1991, individuals of the $3 R N$ genotypes, sharing similar polygenic background, were produced by intercrossing the expected heterozygous animals. Among these individuals, 16 males and 43 females were then progeny tested for RTN, using the tester line, in order to determine their genotype (1992-1993) (Le Roy et al, 1994). Families of the heterozygous animals were retained to constitute the reference population to study the cosegregation of alleles at the $R N$ and at marker loci. 


\section{Reference families}

A segregation analysis of the progeny test data gave the posterior probabilities of individual genotypes (Elsen et al, 1988), under the retained hypothesis of mixed (major gene + polygenes) inheritance of the RTN (Le Roy et al, 1994). Six males and 10 females were classified as heterozygous $R N^{-} / r n^{+}$with a probability higher than 0.95 . In the corresponding backcross families, the probability for each offspring to be $R N^{-} / r n^{+}$or $r n^{+} / r n^{+}$was also estimated. An offspring was kept if the probability of its genotype was higher than 0.90 (on average, the selection rate within a family reached $65 \%$ ). The genotype of the offspring retained, $i e$ the allele received from the heterozygous parent, was then considered as known. Finally, 13 families were chosen from the 16 available, considering the number of offspring (at least 10) and their balanced distribution between the 2 genotypes. Thus, 160 female and 60 male informative meioses for the $R N$ locus were available to constitute reference families of double backcross type (with phase unknown) for each informative marker.

\section{MOLECULAR MARKERS}

\section{Panel of markers}

Assuming that $R N$ genotypes were known, our objective was the choice of a panel of markers constituting a $40 \mathrm{cM}$ map. This choice was made from both the European (Archibal et al, 1995) and USDA (Rohrer et al, 1994) maps. Despite their limited connections, we tried to take advantage of their complementarity.

Among our own markers, already available for analyses on an automatic sequencer, we chose a set of 14 markers located on 10 different chromosomes. Twelve of them were found to be polymorphic in the $R N$ heterozygous parents. A set of 152 microsatellites developed in other laboratories was also collected. When tested on one pig, a satisfying PCR product was observed on agarose gel for 107 markers. Out of these, 77 were selected in order to build the required $40 \mathrm{cM}$ panel. A primer was synthesized and labelled for these 77 markers with one of the fluorescent dyes 6-Fam, Hex or Tamra. From the analysis of one animal, a satisfying pattern on the sequencer was observed for 53 markers. Fifty-one were subsequently found to be polymorphic on the $R N$ heterozygous parents. Therefore, 63 polymorphic markers $(12+51)$ were selected, constituting 20 different linkage groups. An average heterozygosity of $50 \%$ and an average number of alleles of 3.35 were observed. Taking into account the genetic distances reported between the 63 polymorphic markers (Rohrer et al, 1994; Archibald et al, 1995), the estimated length of the genome covered by this panel was $1700 \mathrm{cM}$.

\section{Genotyping and linkage analysis}

The PCR amplifications were performed on a Techne PHC3 thermocycler, under the conditions described by authors of the markers. Depending on the size of the alleles, the PCR products of 4-10 different markers obtained on the same animal were pooled before precipitation. Samples were rediluted in the presence of formamide and Genescan 350 size standard (Perkin Elmer). The electrophoretic migrations 
were performed on $12 \mathrm{~cm}$ gels on a $373 \mathrm{ABI}$ sequencer. Forty-eight animals were analysed on each gel by 2 successive loadings of 24 animals. The size of the PCR fragments was determined with Genescan 1.2.2 software. To ensure verification of Mendelian inheritance, all sibs were analysed on the same gel as their parents.

All data concerning pedigrees, markers and protocols, PCR plates, gels and genotypes were managed with the Gemma 2.26 software (Milan and Woloszyn, 1994). The maximum lod scores and the corresponding recombination fractions between RN and markers were estimated, within sex and globally, using Gemma, and checked using Crimap 2.1.

\section{IDENTIFICATION OF A MARKER LINKED TO THE RN LOCUS}

A first set of 10 markers from our laboratory was analysed on 143 meioses. No linkage with $\mathrm{RN}$ was detected, using the classical threshold of -2 for the lod score (Morton, 1955). This first set allowed us to exclude $540 \mathrm{cM}$ for the location of $R N$ locus.

A second set of 23 markers was then analysed. Linkage between the $R N$ locus and the marker S0088 on chromosome 15 was detected. From 29 male and 93 female informative meioses scored, a distance of $18 \mathrm{cM}$ (Kosambi function) was estimated, with a lod score of 10.1. This value is well above the corrected rejection threshold of $3+\log _{10}$ (number of markers) $=4.5$ (Ott, 1991). The male distance was $7 \mathrm{cM}$, whereas the female distance was $22 \mathrm{cM}$ (table I). Larger distances were found for the other marker of the panel belonging to chromosome 15, and did not permit a more precise localization of $R N$.

Table I. Results of the analysis of linkage between the $R N$ and S0088 loci.

\begin{tabular}{lcccc}
\hline & $\begin{array}{c}\text { Number of informative } \\
\text { meioses }\end{array}$ & $\begin{array}{c}\text { Number of } \\
\text { recombinants }\end{array}$ & $\begin{array}{c}\text { Genetic distance } \\
\text { (Kosambi cM) }\end{array}$ & Lod score \\
\hline Male & 29 & 2 & 7 & 5.0 \\
Female & 93 & 19 & 22 & 5.8 \\
Both sexes & 122 & 21 & 18 & 10.1 \\
\hline
\end{tabular}

* Most likely phase assumed.

It has been reported that the S0088 marker is closely linked $(3 \mathrm{cM})$ to the DPP 4 gene (Ellegren et al, 1994), which is located in 15q2.1 (Thomsen et al, 1993). The $R N$ locus might thus be located in the region 15q1.5-q2.3. Based on this preliminary mapping of the $R N$ locus, efforts are now placed on finding closer markers, using microsatellites located in this region of chromosome 15. Further work will also be carried out on testing candidate genes in a comparative map approach. 


\section{ACKNOWLEDGMENTS}

Thanks are expressed to MF Rothschild (Iowa State University, Ames, USA) for the generous gift of samples of primers for 152 markers. We acknowledge the technical assistance of M Bonnet and Y Billon. This work was supported with grants from INRA Agrobio and Prodige, GREG and EC Bridge programmes.

\section{REFERENCES}

Archibald A, Brown J, Couperwhite S et al (1995) The PiGMaP consortium linkage map of the pig (Sus scrofa). Mamm Genome (in press)

Ellegren H, Chowdhary B, Johansson et al (1994) A primary linkage map of the porcine genome reveals a low rate of genetic recombination. Genetics 137, 1089-1100

Elsen JM, Le Roy P (1989) Simplified versions of segregation analysis for detection of major genes in animal breeding data. Proc 40th Ann Meeting EAAP, Dublin, Ireland, Trinity College, Dublin, Ireland, I, 57-58

Elsen JM, Vu Tien Khang J, Le Roy P (1988) A statistical model for genotype determination at a major locus in a progeny test design. Genet Sel Evol 20, 211-226

Gellin J, Chevalet C (1994) Stratégie d'établissement des cartes génétiques. Exemple du porc. Genet Sel Evol 26, 35s-51s

Le Roy P, Naveau J, Elsen JM, Sellier P (1990) Evidence for a new major gene influencing meat quality in pigs. Genet Res (Camb) 55, 33-40

Le Roy P, Caritez JC, Elsen JM, Sellier P (1994) Pigmeat quality: experimental study on the RN major locus. Proc 5th World Congress Genet Appl Livest Prod, Univ Guelph, Guelph, ON, Canada, 19, 473-476

Le Roy $\mathrm{P}$, Caritez JC, Billon Y et al (1995) Etude de l'effet du locus $R N$ sur les caractères de croissance et de carcasse: premiers résultats. Journ Rech Porcine Fr 27, 165-169

Milan D, Woloszyn N (1994) GEMMA: a laboratory database to manage genotyping. Technical paper, INRA, Toulouse, France, 29

Morton NE (1955) Sequential tests for the detection of linkage. Am J Hum Genet 7, 277-318

Naveau J (1986) Contribution à l'étude du déterminisme génétique de la qualité de viande porcine. Héritabilité du rendement technologique Napole. Journ Rech Porcine Fr 18, 265-276

Naveau J, Pommeret P, Lechaux P (1985) Proposition d'une méthode de mesure du rendement technologique : "la méthode Napole". Techni-porc 8, 7-13

Ott J (1991) Analysis of Human Genetic Linkage. The Johns Hopkins University Press, Baltimore, MD, USA

Rohrer GA, Alexander LJ, Keele JW, Smith TP, Beattie CW (1994) A microsatellite linkage map of the porcine genome. Genetics 136, 231-245

Thomsen PD, Qvist H, Marklund L, Andersson L, Sjöström H, Noren O (1993) Assignment of the dipeptidylpeptidase IV (DPP4) gene to pig chromosome 15q2.1 Mamm Genome 4, 604-607 